\title{
As canções: fabulação e ética da invenção em Eduardo Coutinho ${ }^{1}$
}

/////////////////// Fernando do Nascimento Gonçalves ${ }^{2}$

1. Texto originalmente apresentado ao Grupo de Trabalho Comunicação e Sociabilidade do XXI Encontro da Associação Nacional dos Programas de Pós-Graduação em Comunicação, ocorrido na Universidade Federal de Juiz de Fora, em junho de 2012.

2. Doutor em Comunicação pela Universidade Federal do Rio de Janeiro, professor e pesquisador do Programa de Pós-Graduação em Comunicação da Universidade do Estado do Rio de Janeiro.

E-mail: azert46@yahoo.com 


\section{Resumo}

Este texto discute os aspectos relacionais e subjetivos dos processos de criação de Eduardo Coutinho, particularmente em seu novo filme, As canções. Apoiado principalmente nos conceitos de fabulação e de ritornelo de Deleuze e Guattari, o texto buscará analisar seu modo de fazer cinema não como questão autoral, mas como prática de produção subjetiva, o que permite considerar esse seu fazer cinema como prática comunicativa pertencente a um território de invenção e a uma ética do acontecimento, como a entende Badiou.

\section{Palavras-chave}

Comunicação, cinema, produção de subjetividade, máquina estética, Eduardo Coutinho.

Abstract

This paper discusses the relational and subjective aspects of Eduardo Coutinho's creation processes, particularly in his new movie, As canções. Fundamented on the concepts of "fabulation" and "ritornello" by Deleuze and Guattari, the paper seeks to analyze Coutinhos's modes of filmmaking not as an "authoral matter", but as a practice of subjective production. I here suggest that his filmmaking processes can be seen as a communicative practice which belongs to a territory of invention and to an ethics of the event, as Badiou understands it.

Keywords

Communication, cinema, subjectivity production, aesthetic machine, Eduardo Coutinho. 


\title{
Introdução
}

\author{
Repetir repetir - até ficar diferente \\ Repetir é um dom de estilo
}

Manoel de Barros

3. A abordagem deste texto é inspirada na teoria ator-rede (TAR), ou sociologia das associações, sistematizada por Bruno Latour. A sociologia das associações ou da tradução (ou TAR) é uma forma de abordar os fenômenos sociais em processo de sua constituição, e não apenas quando já estão "prontos". A especificidade da TAR reside em não reduzir a feitura dos

objetos em análise à observação dos vínculos e das interações, mas em acentuar a ação, o trabalho de fabricação e transformação
O presente texto tem como proposta discutir o último filme de Eduardo Coutinho, As canções, embora a partir de um olhar não propriamente do cinema, mas sim dos processos de subjetivação. Nesse sentido, o filme nos interessará pelas pistas deixadas nele pelo realizador, que nos permitem rastrear e explorar, como diria Bruno Latour $(2008)^{3}$, as conexões que nos transportam e nos conduzem para dentro das redes que formam seu "território de invenção".

Como os outros filmes de Coutinho, As canções constitui uma prática comunicativa que se inscreve no que chamaremos de uma "ética de invenção", que aqui entenderemos como um processo de fidelidade ao acontecimento (BADIOU, 1995); no caso, o engajamento com um projeto de produção de diferença e de intensidades. Por isso mesmo, seu modo de fazer cinema pode ser caracterizado como uma máquina estética produtora de modos de vida e visões de mundo singulares. Mas esse novo filme nos sopra uma chave de leitura que parece ser particularmente útil para explorar os aspectos relacionais e subjetivos de sua ética da invenção dada a ver por seu modo de fazer cinema. 
presente no que ele chama de redes sociotécnicas, séries heterogêneas compostas de elementos animados

(humanos) e inanimados (não

humanos) conectados, que se agenciam e se afetam mutuamente.

A noção de rede em Latour não tem a ver com a de sistema, e sim com a de fluxo e com conjuntos de relações entre pessoas e coisas que formam determinadas configurações e estabilizações (um tipo de discurso, uma determinada ideia, valor, prática ou modo de fazer e uma visão de mundo que fazem que certas coisas aconteçam

do jeito que acontecem). Nessa rede de relações, pessoas e coisas são simetricamente consideradas atores (um celular, um filme, um

livro, uma canção, um museu, uma regra, um discurso, um procedimento, tanto quanto um realizador, um pesquisador, um curador, um crítico etc.). Nessa perspectiva, o interesse do pesquisador consiste em seguir o trabalho de fabricação dos fatos, dos sujeitos, dos objetos; fabricação que se faz em rede, através de alianças entre atores humanos e não humanos.
Em princípio, As canções é um filme despretensioso sobre música, afeto e memória. Sobre como pessoas comuns associam experiências de vida a canções com que se identificam ou então sobre como cultivam a lembrança de fatos que se deram num passado que para elas não terminou. O filme torna pertinente o dito popular "recordar é viver", mas o faz por tratar de uma questão que me pareceu central no filme: ele não parece falar tanto de canções e histórias que expressam as lembranças de um vivido, mas sim das intensidades e dos devires disso que é guardado na lembrança e que, ao ser transformado em forma-história e forma-canção, se torna matéria expressiva para o filme.

Ao texto interessará, na verdade, tomar esses dados como ponto de partida para tratar de dois aspectos comunicativos que aparecem recorrentemente na obra de Coutinho: primeiramente, a capacidade de invocar ou provocar sensações e intensidades e de traduzi-las em forma-filme e, em segundo lugar, a capacidade de "criar repetindo" e de produzir assim um lugar de enunciação singular através de repetições e variações.

O filme As canções me chamou a atenção justamente por realizar essa operação tão comum no cinema de Coutinho: a de ativar fragmentos do mundo e da experiência do outro e fazê-los tornar-se obra de arte. E essa será a questão que nos guiará no texto: como é possível, em seu projeto estético e poético, o filme produzir esse efeito? O pensamento de Deleuze e Guattari nos forneceu pistas valiosas. Assistindo ao filme, me ocorreu, por exemplo, que, talvez, como afirmam esses autores ao tratar do que chamaram de "afectos" e "perceptos", aquilo que perdura (uma dor, uma alegria, uma saudade) não perdura por causa do cultivo da lembrança. O que perdura seriam os "blocos de sensações" de dor, de saudade, de perda, de amor, que se colariam a uma lembrança que se expressa na forma de história ou canção e que permitem essas sensações retornarem sempre como um "motivo" no filme. Exatamente porque, como coloca Bergson ao tratar dos modos de funcionamento da memória e de reconhecimento das imagens, a lembrança é já uma forma de representação e, como tal, é uma ação (BERGSON, 1999, p. 87). 
O que parece singular é que o filme vai trabalhar não com as lembranças em si, mas com as sensações que impregnam as narrativas dessas experiências. São tais sensações que são tomadas por Coutinho como um "presente" que é revivido e refeito a partir primeiramente do que Bergson (1999, p. 88) chamou de “imagenslembranças" - formas primeiras de um registro de memória. Contudo, como coloca Bergson, há também um segundo tipo de memória, que se produz a partir da fixação e do alinhamento de uma lembrança no presente. Esse aspecto de continuidade implica para Bergson uma mudança, uma outra disposição para a ação implicada no ato da rememoração. É essa segunda experiência de memória que parece interessar a Coutinho. E o filme nos interessa exatamente por permitir ver o trabalho realizado com essa segunda forma de memória, atravessada pelos elementos e pelas circunstâncias que a fazem emergir e ser revivida e "agida", como diz Bergson, e que vão ser mobilizados como matéria expressiva e como "motivo", a partir das formas narrativas "história" e "canção". O texto buscará, então, chamar a atenção para como, a partir das sensações das lembranças revividas, as narrativas são transformadas nessas qualidades expressivas que vão servir de base para a construção do filme.

A partir da descrição desse trabalho intensivo com as formas narrativas que o filme faz, o texto irá discutir os procedimentos característicos da linguagem de Coutinho, porém menos enquanto técnica ou marca autoral e mais como processo de subjetivação que confere à sua obra uma qualidade singular que contamina o filme e também quem a ele assiste.

\section{Seguindo uma trilha}

Em 9 de dezembro de 2011, Eduardo Coutinho lançou seu último filme, As canções. Mas a ideia do projeto, segundo ele, é antiga e teria surgido do desejo de fazer um filme só com músicas de Roberto Carlos. A complexidade da operação, simples apenas na aparência, somadas ao custo dos direitos autorais, teriam feito Coutinho desistir do trabalho. Anos depois, a ideia é retomada, e o filme é realizado em um mês e meio de pesquisa, três dias de 
filmagens e dois meses de montagem. "Foi o filme mais fácil, feliz e tranquilo que fiz na minha vida", afirma em entrevista ao Jormal do Commercio, em 6 de janeiro de 2012.

O filme mostra 18 pessoas que se propõem a cantar canções que marcaram suas vidas, explicando também os motivos pelos quais consideram tais músicas tão importantes. O que poderia ser um tema banal para um filme ganhou nas mãos de Coutinho características singulares e potentes. A estrutura é simples e parecida com a de Jogo de cena, de 2007: pessoas que desejam participar do filme contando suas histórias participam de uma espécie de audição, na qual são ou não selecionadas. Tudo se passa no interior de um teatro vazio, sem externas. Em Jogo de cena, algumas pessoas aparecem subindo as escadas mal iluminadas, entrando pela coxia até chegar ao palco, onde Coutinho, sua equipe e uma cadeira vazia as esperam. No novo filme, na maioria das vezes, as pessoas já estão lá, sentadas de frente para Coutinho e para a plateia, na posição inversa à de Jogo de cena.

As tomadas são feitas quase sempre em close e plano médio. Algumas pessoas aparecem logo cantando sua música e contam a história depois. Outras já são mostradas iniciando suas narrativas e cantando em seguida, eventualmente voltando a conversar com Coutinho. Outras ainda aparecem entrando no palco, sentando-se em frente a Coutinho e sua equipe, passando então a cantar ou a contar as histórias. Quatro apenas cantam.

Histórias e canções se sucedem no interior do teatro, tendo como fundo suas cortinas escuras. Os olhos nunca encaram a câmera, e sim Coutinho. Os olhares estão sempre levemente de lado, como para indicar a posição do realizador, ao lado da câmera. A iluminação fraca e o enquadramento do rosto ou de parte do corpo contra o fundo escuro ajudam a criar uma ambiência de grande intimidade, muito próxima da obtida em Jogo de cena.

Podemos perceber parte dessas operações também em filmes como Edifício Master, de 2002. Embora também sem externas, a tomada do depoimento parece ali ser mobilizada por outra questão, e os modos de vida expressos no falar de si são atravessados pela circunstância do viver em Copacabana. Ali, a produção da 
intimidade tão cara ao cinema de Coutinho é organizada no interior de um prédio de conjugados, na própria casa das personagens. A história era outra. Outra ainda era a de um filme como Babilônia 2000, que já tem externas, e a equipe aparece em seu trânsito pela favela do Leme; isso tudo fazendo parte do filme sobre as expectativas dos moradores sobre o ano 2000.

Ainda assim, percebe-se claramente em todos esses filmes, e em outros também, que há sempre uma circunstância em torno da qual se organiza o fazer filme de Coutinho, circunstância que funciona como uma regra de jogo que catalisa elementos que vão potencializar o efeito dos depoimentos. Observa-se também nesses filmes sempre a intenção de produzir uma ambiência para as histórias e fazer que elas nos contem algo que parece estar além delas próprias.

Em As canções isso se repete, mas o silêncio, a luz e a ambiência de intimidade em torno da qual se desenrola o filme têm uma função importante e são quase personagens. A própria circunstância escolhida - pessoas deveriam cantar canções que marcaram suas vidas e contar por que - parecia exigir isso. Esses elementos, somados à montagem e às intervenções de Coutinho, conferiam uma qualidade particular aos depoimentos.

Na primeira vez em que assisti ao filme, me impressionou sobretudo o fato de eu não ter me cansado durante uma hora e meia vendol 8 pessoas em close e plano médio, paradas, sentadas quase o tempo todo, cantando e contando histórias de suas vidas. Ainda assim me senti tocado por tudo aquilo. Eis a história. Uma história cuja intensidade se nutre de algo que me fez lembrar o narrador de Benjamin, que retira da própria experiência o que conta e que "incorpora as coisas narradas à experiência dos seus ouvintes" (BENJAMIN, 1993, p. 201). Essa me parece ser uma porta de entrada para o universo de criação do realizador, que nos ajuda a ver seu modo de fazer cinema como um dispositivo de invenção que se formaliza e opera na forma-filme.

Uma das personagens que me fizeram pensar nisso foi Lídia, uma mulher separada com quatro filhos, que na década de 70 conheceu um senhor de 70 anos de quem se tornou amante. Ela 
conta que na época tinha seus 30 anos. "Ele era um mulato forte, parecia bem mais novo, uns 50 anos.” Algo nela parecia se pôr em movimento enquanto falava. Conta que "pariram" logo um filho e que depois disso o homem perdeu um pouco o interesse por ela. Disse que ele gostava dela mais pelo sexo e que ela gostava dele todo, mas ainda mais do dinheiro que ele lhe dava. "Ele era bonito?", pergunta Coutinho. "Era bonito, sim", responde. "Cheiroso! Ele usava Sândalus!”, completou, com gosto.

A canção que marcou sua vida foi a mesma que ouvia no rádio do Simca Chambord dele, toda vez que saíam juntos. Ao cantar O tempo vai apagar, de Roberto Carlos, Lídia se emociona e quase chora. Lembra que uma vez no carro tiveram um desentendimento. Decidiu comprar uma arma. Um dia, quando saíram novamente, tomada de ódio, tentou matá-lo no carro, mas a bala não saiu. Seus olhos marejaram novamente. Coutinho pergunta se quando ela canta essa música isso traz mágoa, se foi bom ou ruim. "Foi muito bom!", diz sem pensar, visivelmente emocionada. Em seguida, se levanta e sai do palco. A cena termina com a imagem da cadeira vazia na qual se sentara e o som de seu choro por detrás da cortina, por alguns segundos.

Mais do que a história e a canção de Lídia, chamou-me a atenção a qualidade dessa emoção que foi posta em cena pelo filme. É isso que a obra ativa e repete com suas 18 personagens. As canções e as histórias aparecem como um recurso que Coutinho vai empregar para que cada cena fale da mesma coisa e, ao mesmo tempo, seja única. É assim que ele vai fazendo do filme um lugar de enunciação singular através de variações. Curiosamente, o próprio filme parece ter surgido de uma repetição criadora. As canções me fez pensar no final de Jogo de cena (2007) - filme só com histórias —, quando a personagem Sarita decide voltar para "completar" seu depoimento. Dizendo ter ficado com a impressão de que seu discurso deixara um tom amargo, ela retorna para torná-lo mais leve, cantando Se essa rua fosse minha, de forma emocionada, mas alegre.

De repetição em repetição, é sempre algo novo que retorna por força mesmo disso que retorna. Os recursos da música e da história são, na verdade, apenas algumas das marcas do cinema 
de Coutinho. Assim como, por sua vez, Jogo de cena não foi o primeiro filme no qual música e história aparecem e têm uma função expressiva - também outros recursos aparecem de forma recorrente. É possível perceber em Coutinho todo um conjunto de elementos que produz uma marca e a confere a seu cinema. $\mathrm{Na}$ verdade, Coutinho lança mão de um "sistema estruturante", que mobiliza e organiza as formas narrativas: as regras de filmagem, o princípio da locação única, os closes, as intervenções do realizador durante a fala dos personagens, a montagem. Porém, não é apenas isso que ele repete. Em vários de seus filmes (sobretudo em Jogo de cena e Edifício Master, mas também em Babilônia 2000), apesar de mudarem os temas, as questões, as locações e os procedimentos, o que não muda é o desejo de produzir encontros e sua intenção de produzir intensidades com eles, de fazer que eles se tornem "outra coisa". Eis o princípio do que estou chamando de uma "ética de invenção", que ele faz retornar e, ao mesmo tempo, variar, por questão de fidelidade aos processos de produção de diferença.

Podemos entender esse investimento, que estou considerando propriamente ético, a partir de Badiou (1995), para quem "ética" não será vista como um princípio de relação com o que se passa ou como princípios que regulam ou balizam nossas opiniões, comentários ou posições sobre uma dada situação (como os direitos do homem), e sim como algo calcado nas próprias situações, e não em situações abstratas, que as enquadrariam como verdades. Para Badiou, a noção de "ética" está acoplada à de "acontecimento", que para esse autor seria uma espécie de irrupção de uma inscrição ordinária do sujeito numa dada situação. É essa decisão por referir-se a uma situação do ponto de vista de um acontecimento que Badiou (1995, p. 54) chamou de "fidelidade". O que vejo em Coutinho é exatamente um fazer cinema que pertence a um processo contínuo de invenção, a uma persistência/fidelidade inscrita na produção de acontecimentos. Criar apoiado na repetição e na variação das condições de possibilidade de produção de um acontecimento: eis a ética de invenção de seu fazer cinema, eis sua persistência.

Vejo nessa intenção de Coutinho de fazer repetir, mas também de fazer retornar sempre uma operação que se aproxima do conceito que Deleuze e Guattari (1980, p. 383) chamaram de 
"ritornelo". Ritornelo seria uma espécie de "motivo", aquilo que se repete e muda, que sempre retorna e demarca um "território" que é já expressão do ritmo de uma variação criadora, de um agenciamento. Essa perspectiva coincide, por sua vez, com o princípio de “instabilidade do homogêneo" em Gabriel Tarde, uma das fontes de inspiração desses autores. Em sua sociologia do infinitesimal, Tarde (2007) faz uma aposta numa "transitividade intrínseca do mundo" como princípio da diferença. Para Tarde, só existem diferença e variação da diferença. O homogêneo seria apenas um momento dessa variação.

Esse princípio parece estar presente também no conceito de "transdução" de Simondon, em que a questão da variação aparece mais clara. Para Simondon (1964, p. 18), a partir da transdução, “operação física, biológica, mental, social, pela qual uma atividade se propaga gradativamente no interior de um domínio", seria possível produzir passagens de um estado a outro, de um meio a outro, constituindo um novo plano. Continua ele: "No domínio físico, ela [transdução] se efetua sob a forma de repetição progressiva, mas em domínios mais complexos como o vital, por exemplo. Em razão da metaestabilidade, a operação transdutora adquire constante variação, estendendo-se a domínios heterogêneos" (SIMONDON, 1964, p. 18).

É no ritmo dessas "repetições progressivas" que a "diferença vai diferindo", como propõe Tarde. É nesse ritmo finalmente que se produz a "repetição produtiva” que Deleuze e Guatarri (1980, p. 391) chamaram de "estilo", que é mais que a marca distintiva que eles chamaram de "assinatura”. Para os autores, a assinatura e o estilo não seriam marcas identitárias que remeteriam a um sujeito. A assinatura seria antes uma "marca territorializante", que aponta para a formação de um domínio, de um território existencial, um conjunto de relações próprias a um determinado universo de sentido e de valor. Por sua vez, o estilo não diz respeito a tipos de uso ou modo de ser de sujeitos. Exprime antes os modos de relação próprios a um "território", os modos como se dão as dinâmicas entre os impulsos internos que o formam e as circunstâncias externas que o fazem variar. $O$ estilo remete, finalmente, ao 
ritornelo, que Deleuze e Guattari (1980, p. 383) definem com um “agenciamento territorial”, uma dinâmica de formação e continuidade de um território existencial. O ritornelo é o ritmo e a melodia "territorializados", porque tornados expressivos por marcas como assinatura e estilo.

Assinatura e estilo seriam um "meio" através do qual se produz um ritmo, uma repetição periódica, que não tem outro efeito senão produzir uma diferença pela qual se passa para um outro meio. É a diferença que é rítmica, e não a repetição que, no entanto, a produz. No caso, o modo de fazer cinema de Coutinho parece ser uma "assinatura", mas a linguagem de seu cinema seria "estilo", modo de inscrição de seu fazer cinema no ritmo e no ritornelo de um "território de invenção", em que esse "fazer cinema" pode se repetir variando e tornar-se um dispositivo fabulador produtor de acontecimento.

\section{Do filme-dispositivo ou dispositivo-filme}

De fato, ao fazer seus filmes, Coutinho não está buscando, como bem observou Consuelo Lins (2007), apresentar sua visão sobre o mundo, mas fazer o mundo apresentar-se. É dessa intenção que seu "sistema estruturante" forjará para a obra uma linguagem, conferindo-lhe uma marca, um território. Assim como o que importa para a arte é a individuação da linguagem, e não a expressão pessoal, a repetição e a variação são para Coutinho mais que um cartão de visitas, são constitutivos de seu fazer fílmico, algo que faz parte do que Consuelo Lins chamou de filmedispositivo (LINS, 2007).

Ao tratar do dispositivo no documentário e na obra de Coutinho, Lins, de partida, esclarece: o dispositivo não diria respeito nem à captação das imagens nem à sua exibição. É uma máquina relacional, "uma máquina que provoca e permite filmar encontros. Relações que acontecem dentro de linhas espaciais, temporais, tecnológicas, acionadas por ele cada vez que se aproxima de um universo social” (LINS, 2007, p. 47). Lins percebe a presença dessa “máquina” em Coutinho, mas também em outros realizadores, 
como Cao Guimarães, João Salles, Sandra Kogut e Kiko Goifman. Afirma que o que eles teriam em comum é o fato de considerarem que "o mundo não está pronto para ser filmado, mas em constante transformação" e que "a filmagem não apenas intensifica essa mudança, mas pode até mesmo provocar acontecimentos para serem especialmente capturados pela câmera". O que caracterizaria o que Lins chamou de filme-dispositivo é que ele implica, ao mesmo tempo, um pensamento e um artifício, dados por condições, regras, limites para que o filme aconteça: “um procedimento produtor, ativo, criador de realidades, imagens, mundos, sensações, percepções que não preexistiam a ele" (LINS, 2007, p. 47).

Essa concepção de dispositivo nos interessa também, em certa medida, porque acentua o aspecto de produção de um efeito e de maquinação. Contudo, partindo do campo do documentário e do cinema, o termo parece ser impregnado do sentido de procedimento, de estratégia narrativa, isto é, da própria "maquinação". Essa perspectiva é que permite a Lins propor sua noção de "filme-dispositivo" e é extremamente útil para suas análises do documentário contemporâneo, da videoarte e das videoinstalações. Nessa concepção de dispositivo, mesmo que os procedimentos se repitam, há sempre uma rearticulação deles em função de novas determinações, como afirma Lins. Contudo, não é essa a "repetição na diferença" que vai interessar aqui. Diria que estou menos interessado no filme enquanto dispositivo e mais no dispositivo enquanto filme.

Desejo explorar, por exemplo, aquilo que no filme de Coutinho a mim parece "ultrapassar" essa "maquinação”, aquilo que minha intuição inicial, ao ver As canções pela primeira vez, me fez pensar como não sendo pertencente de todo a Coutinho, mas ao "seu cinema", ao território do qual seu "fazer filme" faz parte. Por essa razão, a partir daqui, vou preferir me servir da noção de dispositivo dentro de uma perspectiva mais geral, como conjunto complexo de relações em que tais maquinações se inscrevem. Para tanto, me aproximarei do conceito de “agenciamento maquínico” em Deleuze e Guattari (1977), que, a meu ver, atenderá mais precisamente ao modo como estou 
tentando desenvolver meu pensamento sobre As canções - não só como filme, mas como figura de um agenciamento que se inscreve em um universo de sentido e de valor próprio à ética de invenção da qual faz parte o cinema de Coutinho.

\section{O dispositivo fabulador}

Ózio é feirante e vive sozinho em São Gonçalo, no Grande Rio. Tem um sítio em Santa Maria Madalena, no norte fluminense. Com seu jeito matuto, conta que perdeu "três mães" de uma vez: a mãe, a sogra e a mulher. Diz que, quando conheceu uma nova companheira, resolveu compor uma canção para sua primeira esposa ficar bem longe dele. Coutinho pergunta como é isso. Ele responde cantando Toada: "Vai simbora meu bem, vai simbora [...]". A música é triste, tem um tom de lamento, e ele a canta com um olhar perdido e um tom pungente que exprime o que parece ser uma dor de perda e de saudade. Coutinho pergunta se ele canta isso para outras pessoas, e ele diz que não, que fez para ele mesmo cantar na roça, assoviando. Em seguida, diz que já está na hora de ir embora. Levanta-se, ajeita a pochette em volta da cintura, se despede de Coutinho e da equipe com um aceno acanhado e sai. Close na cadeira vazia no palco por alguns segundos.

Para Coutinho, não são as histórias, as canções ou as emoções em si o que parece importar, e sim momentos em que algo irrompe e se torna grande e especial naquilo que é simples e corriqueiro. Momentos do filme, por exemplo, quando um homem chora por uma coisa pela qual em princípio não teria que chorar, lembrando-se da canção que a mãe cantava quando era pequeno, estando a mãe ainda viva.

O homem é Gilmar. Ele conta que era casado com uma mulher evangélica com quem passou a ir à igreja, em cuja banda passou a tocar. Diz que, depois que sua mulher morreu, parou de frequentar a igreja porque conheceu uma outra companheira e foi proibido de tocar na banda porque não era casado. Coutinho pergunta então qual era a sua música, e ele diz que era Esmeralda, de Carlos José: 


\begin{abstract}
Vestida de noiva, com véu e grinalda/Lá vai Esmeralda casar na igreja./Deus queira que os anjos não cantem pra ela $[\ldots] /$ Deus queira que à noite, na hora da festa/Não venha orquestra, não venha ninguém/Pra ver Esmeralda, com véu e grinalda/Nos braços de outro que não é seu bem./Quem devia casar com ela era eu, sim senhor!/ Quem devia casar com ela era eu, seu amor!
\end{abstract}

Gilmar canta a canção de olhos fechados, visivelmente emocionado. Ao terminar, explica que a canção o marcou, muito embora nunca a tenha ouvido no rádio. Conta que não sabia que conhecia a música toda, que ela simplesmente "ficou na cabeça". Então explica que era sua mãe, costureira, que a cantava em casa quando ele era criança, enquanto cortava moldes para as roupas que fazia. De repente, ele chora. Meio constrangido, diz não saber por que isso aconteceu, pois a canção "traz coisa boa”, e sua mãe está bem, não morreu. Coutinho termina a cena dizendo baixinho que coisas boas às vezes também fazem chorar.

São instantes como esse que interessam ao realizador, pela qualidade expressiva liberada na narrativa. Mas se, para o filme, é importante produzir essas intensidades, é importante perceber que Coutinho não obtém essa qualidade do vivido apenas apoiado em sua autoridade de metteur-en-scène ou nas maquinações de seu "filmedispositivo". Há outra coisa que parece se produzir a partir e através de seus procedimentos, mas que ao mesmo os ultrapassa. Algo que não depende totalmente do realizador. Algo que ele organiza sem, porém, determinar. É que Coutinho e seus personagens parecem se inscrever naquilo Deleuze e Guattari (1992) chamaram de uma "função fabuladora", em que o que importa não é tanto o que se conta, mas as intensidades que surgem do que é contado. O que importa é um tornar-se outro na narrativa.

Para esses autores, na fabulação, há como que um ultrapassamento, algo que atinge uma qualidade particular, em que o "pequeno" se torna "gigante", e o "menor", mais "poderoso". E esse "gigante" é real, existe em sua verdade. Isso ocorreria, segundo eles, pois na arte o trabalho intensivo com as formas expressivas permite ao artista "exceder os estados perceptivos e 
as passagens do vivido", estados esses que eles vão chamar de "perceptos" (DELEUZE; GUATTARI, 1992, p. 222-223). A fabulação seria essa operação em que o ato de narrar é parte da produção de um "percepto".

Ao afirmar que o que lhe interessa são exatamente as reações surpreendentes e involuntárias, como no caso de Gilmar, que chora e deixa vir à tona algum segredo, sem intenção de fazê-lo, o que Coutinho afirma é esse lugar de produção de perceptos. É esse lugar que lhe fornece inclusive a "assinatura" através da qual podemos reconhecê-lo como realizador. Em Coutinho, a narrativa é o canal; o filme, o potencializador; a fabulação, o objeto do dispositivo-invenção.

Isso parece ficar claro quando Coutinho afirma em entrevista (BARROS, 2012) que se interessa no filme por gente que revive e reinventa o passado e que para ele isso é mais verdadeiro do que o vivido; ou então quando diz que, se o afeto foi uma questão essencial para a realização do filme, ele não importa em si mesmo, mas, sim, na medida em que dele pode emanar uma qualidade singular. Do mesmo modo, os modos que elege para produzir encontros para tratar de fatos do mundo criam certamente circunstâncias particulares que afetam os modos como as narrativas são produzidas. Contudo, o que Coutinho parece querer afirmar não é uma verdade dos fatos, mas a da invenção das narrativas, a verdade da ficção, finalmente, do jogo das cenas que inclui e articula tanto a performance das personagens quanto a dos procedimentos do próprio Coutinho.

Nesse sentido é que vejo seus filmes como um dispositivo fabulador que, ao mesmo tempo que cria as condições da narrativa, também as deixa livres para proliferarem e liberarem intensidades através das dinâmicas com as matérias expressivas que o realizador mobiliza. Se esse aspecto de "dispositivo" parece adequado para tratar das obras de Coutinho, isso não acontece apenas por ele nos deixar vislumbrar as maquinações que permite ao cineasta investir o documental e o ficcional de um frescor e de uma intensidade que se faz no instante. Mas por fazer perceber o que é constitutivo da poética e do potencial estético das obras: seu universo de sentido e de valor, que funciona como uma espécie de "máquina estética”. 
Quando proponho pensar o filme de Coutinho como um dispositivo com função fabuladora, estou considerando o sentido que esse termo vai assumir ao remeter, em Deleuze e Guattari, ao conceito de "agenciamento". Quando falam de agenciamentos, os autores afirmam que eles são modos coletivos de enunciação e, ao mesmo tempo, agenciamentos "maquínicos" de desejo (DELEUZE; GUATTARI, 1977, p. 118). Para esses autores, o agenciamento seria uma espécie de conjunto de engrenagens conectivas que permitem a formalização de lógicas sociais e discursivas em torno das quais se organizam coisas, pessoas e ações. É com essa natureza "maquínica" do agenciamento, própria dessa concepção de dispositivo, que irei trabalhar a partir de agora.

Para Deleuze e Guattari, pertencemos a certos dispositivos e neles agimos. Com base nesse princípio, penso que o cinema de Coutinho é parte de um dispositivo que estou chamando aqui de dispositivo fabulador. Ou seja, o filme se inscreveria num "fazer cinema" que é enunciado de um agenciamento de invenção no qual Coutinho se inscreve e no qual faz entrar também seus procedimentos, personagens e discursos, todos já engrenagens desse agenciamento.

Foi a partir dessa perspectiva que considerei a obra de determinados artistas como uma "máquina estética", produtora de "afectos" e "perceptos". Foi o caso de Laurie Anderson, por exemplo, que desenvolve todo um trabalho em torno da narrativa apropriando-se das tecnologias de comunicação para discutir a sociedade americana e a cultura tecnológica. É próprio de sua linguagem artística um trabalho intensivo de combinação e recombinação de imagens, objetos, espaços e discursos. Suas obras têm também esse aspecto de "dispositivo", através do qual a artista pode falar às pessoas a partir de experiências banais e, ao mesmo tempo, ligá-las a questões mais amplas, sobre cultura, tempo, poder, tecnologia e identidade. 


\section{A máquina estética e a artesania da comunicação}

Ao assistir a As canções, dei-me conta pela primeira vez da natureza "maquínica" do cinema de Coutinho, e não apenas da de seus procedimentos. Como ocorre com Laurie Anderson e outros criadores, existe no filme um trabalho muito intenso com as formas narrativas, que chamei de "artesania da comunicação" (GONÇALVES, 2006, p. 192). Cunhei o termo para tratar das criações de Anderson, mas acredito que seu princípio esteja presente também em Coutinho - e de forma contundente em As canções. Mas, assim como ocorre em Anderson, em Coutinho, a artesania se inscreve numa "função fabuladora" que preexiste a esse trabalho intensivo com a narrativa. No filme, a artesania está em criar e efetivar as condições desse trabalho e na disposição para eleger os componentes de expressão, dotá-los de qualidades singulares, potencializá-los e nos contaminar com eles.

Isso ficou claro para mim logo na abertura do filme, com a imagem de uma mulher cantando sua música, como se com ela Coutinho desejasse mostrar o tom do filme, seu rosto, sua cor. Essa mulher, mais tarde saberíamos, é Sonia, a quarta personagem. É interessante perceber como ali Coutinho já busca introduzir uma qualidade do filme através de uma pequena série de escolhas, cruciais, porém, para a produção do efeito de nos instalar no "clima" do filme. A primeira é abrir diretamente com alguém cantando; a segunda, começar com uma determinada pessoa cantando; e a terceira, exibir um determinado trecho dessa pessoa cantando. Logo me perguntei por que essas escolhas me pareceram acertadas. Inicialmente, apenas me ocorreu que talvez fosse porque, entre todas as personagens, Sonia era aquela que mais tinha mesmo "cara de abertura”. Mas como explicar essa impressão?

Talvez Sonia fosse aquela cuja presença estivesse impregnada de algum elemento geral, de um sentido que havia no filme todo, sem, porém, deixar de ter uma presença individual marcante. Essa impregnação talvez tenha conferido à sua presença um poder de representar o conjunto sem deixar de ser 
ela mesma. Retornamos à fabulação. Ocorreu-me que Sonia era "personagem" e ao mesmo tempo desempenhava uma "função geral” de um agenciamento-fabulação.

Como vimos, na fabulação, uma personagem vale porque se transforma na narrativa. Ela própria "se torna outro quando se põe a fabular sem nunca ser fictícia” (DELEUZE, 1992, p. 183). $\mathrm{E}$ aquilo que a personagem se torna faz dela algo mais real, mais potente. Sonia tornou-se uma "marca". Ela tornou-se a face de um bloco de sensações, aquilo que Deleuze e Guattari (1992, p. 220) chamaram de "afecto": não aquilo que se sente ("afecção"), mas o que nos põe em um estado outro e nos faz ser "um com uma coisa" ou um "devir não humano do homem", como eles explicam. Em suma, Sonia me pareceu a personagem certa para impregnar-nos com a sensação de que ela era alguém cantando uma canção e ao mesmo tempo algo que acontecia enquanto alguém cantava a canção que marcou sua vida. Ela tornou-se esse alguém-algo. Por isso mesmo, é importante notar que sua aparição como "abertura" não tem o mesmo caráter de quando ela aparece ao longo do filme. Ela primeiro é marca, tom; só depois comparece como personagem. Porém, se ambas as formas de presença de Sonia são figuras do dispositivo-filme, sua mise-en-scène é figura da artesania de Coutinho e de sua própria fabulação.

De tudo isso, desejei chamar a atenção exatamente para o ato fabulador com o qual se agencia Coutinho e para seu trabalho com as formas expressivas: a escolha e o arranjo desses elementos produziram um efeito, instauraram uma marca que dizia quase tudo sobre o filme. É assim que com sua artesania ele aciona não apenas a lembrança de uma emoção mas também um bloco de sensação com o qual nos impregna logo de saída.

As lembranças de Sonia, Lídia, Ózio e Gilmar acionam esse "reviver o passado", que, por sua vez, se agencia com a função fabuladora através das formas-canção e das formas-história. Esse mecanismo parece se repetir nos demais personagens do filme. Quase todos contam uma história e cantam uma canção, não necessariamente nessa ordem. Mas a variação não está nisso. Está no instante do contar e do cantar, que é o que ativa sensações que 
ganham quase um colorido próprio, uma qualidade singular à medida que as narrativas são postas em cena pelo filme.

Como no caso de Isabell, a jovem alemã que praticava capoeira em Londres e veio ao Brasil para conhecer melhor a luta-dança. Isabell conta que acabou se apaixonando por um carioca, que namorou durante dois anos e com quem ficou casada por um tendo sido abandonada logo depois. "Ele falou que não me amava mais e que eu tinha que aceitar isso." A história é contada em bom português, carregado de acento e muita objetividade. Mas o que torna sua presença singular enquanto personagem não é tanto sua história, mas o que brota dela. Ela diz que não conseguiu ouvir samba por muito tempo - "samba e bossa nova também podem ser muito tristes, sabe?". Diz que depois de chorar todo dia por quase seis meses decidiu finalmente continuar com sua vida. Conta que o que a ajudou foi justamente um samba: Você me abandonou, de Alberto Lonato da Velha Guarda da Portela. E ali, diante da câmera, ao cantar a canção, algo pareceu se acender nela:

\footnotetext{
Você me abandonou/Ô ô eu não vou chorar/Mas hei de me vingar/Não vou te ferir/Eu não vou te envenenar/O castigo que eu vou te dar é o desprezo/Eu te mato devagar/O desprezo é uma arma perigosa/É pior do que uma seta venenosa /O desprezo para quem sabe sentir/ Muitas vezes faz chorar/Outras vezes faz sorrir.
}

Cada estrofe era cantada com gosto pela jovem, que parecia reviver sua história e se deliciar com sua vingança. Com mais gosto ainda, seguiu dizendo ter tido uma amiga alemã que também sofrera uma grande desilusão amorosa com um brasileiro. "Ensinei a ela o samba. Ela aprendeu e arranjou um namorado rapidinho e se curou”, concluiu, satisfeita.

O filme segue com seus personagens, todos fazendo algo retornar, algo brotar. Todos num "clima” de grande emoção. A ideia de que os personagens eram todos figuras do filmedispositivo de Coutinho, porém, não me pareceu suficiente para entender como um filme com tal estrutura conseguira não só prender minha atenção por 90 minutos sem me cansar, mas, além 
disso, conseguira me tocar ativando em mim lembranças e afetos que se tornariam outra coisa também - este texto, por exemplo. Uma vez que não me identificara pessoalmente com a maioria das histórias nem com as canções, cujas letras desconhecia em sua maioria, ficou a questão.

Logo percebi que meu interesse não era necessariamente por aquelas pessoas, por suas histórias ou canções, mas por algo que acontecia justamente quando falavam e contavam. Algumas das personagens e suas histórias eram de fato pitorescas, divertidas, às vezes surpreendentes, mas ainda assim não era isso que atraíra minha atenção e sustentara meu interesse nas cenas. Não era isso que me fazia sentir uma quase simpatia por todas aquelas narrativas. Comecei a pensar que alguns dos filmes a que assistira de Coutinho tinham me feito sentir essa "simpatia", sem que eu percebesse. Eles sempre tiveram esse poder. Os filmes tinham um pensamento-sensível sobre algo fascinante. Então me ocorreu que eles são um pensamento-sensível capaz de exercer "simpatia” e fascínio pelo mundo e pelo outro.

De fato, me chamara a atenção desde o início uma certa sensação de imersão própria do "assistir a um filme na sala de cinema". Mas, no caso de As canções, essa sensação parecia potencializada pela própria experiência do filme. Era como se a imersão fosse dada pela entrada num outro lugar, que de certa forma me capturava e me transportava. E esse lugar não era ali na sala de cinema. Esse lugar me pareceu ser a impregnação do universo estético e poético de Coutinho. Seu "território subjetivo". Ao longo de todo o filme, ia ficando claro, pelo menos para mim, que o que acontecia ali com os personagens já não era uma simples reprodução do passado através da narrativa. A narrativa é que produz algo que já não se confunde com o passado nem se resume a ele, embora exista nele. Se há rememoração, ela é mais que a convocação e a percepção do vivido, como afirmam Deleuze e Guattari (1992, p. 218). É algo que carrega algo desse vivido, mas que já está para além dele ou que dele independe: seus "afectos" e "perceptos". É isso que retorna com a história e com a canção, é isso que retorna e varia no filme. 
Quando fabulam, os personagens não estão apenas lembrandose de suas histórias de vida nem contando e cantando lembranças de traições, abandonos, decepções e amores: estão invocando "blocos de sensações" de uma traição, de um abandono, de uma decepção, de um grande amor que dura; são esses blocos que são conservados e ganham concretude no ato de cantar e de contar histórias de vida e dos quais a rememoração é o canal; são eles que mobilizam as narrativas e as tornam singulares. As narrativas conservam um algo que não é o próprio vivido, mas sensações desse vivido. Porque as conserva é que a narrativa se investe de uma qualidade própria, se torna fabulação e, ao mesmo tempo, aquilo que Deleuze e Guattari (1980, p. 387) chamaram de "matérias de expressão", que seriam uma espécie de componente, de coisas do mundo que carregam em si qualidades que funcionam como índices ou marcações que vão definir o território onde Coutinho, seu filme e seus personagens se instalam.

\section{Considerações finais}

Eduardo Coutinho ficou conhecido por seus jogos com a ficção no documentário e pelo modo como discute a questão da alteridade. Como artista, Coutinho usa emoções e fatos como matéria-prima para contar histórias sobre o mundo e sobre as relações humanas.

As canções é parte desse ato criador que estabelece um espaçotempo e um conjunto de relações em que as sensações eclodem e constroem um território que lhes é próprio e onde ganham um rosto, um lugar perceptível e durável. É um "monumento" (DELEUZE; GUATTARI, 1992, p. 218) que conserva a sensação e a intensidade na imagem e faz dessa conservação obra. Nela, histórias, canções e personagens fabuladores são, finalmente, a matéria de que se serve Coutinho para produzir e conservar essas intensidades. É por isso talvez que Deleuze e Guattari (1992, p. 218) afirmam que "o ato do monumento não é a memória, mas a fabulação". 
Como tentei demonstrar, a rememoração é, no filme, um veículo da conservação e da irrupção do "ser da sensação" de experiências de vida do outro e dos fatos do mundo, assim como as histórias e as canções são os meios expressivos dessas sensações. São essas sensações e intensidades que o dispositivo-filme em Coutinho produz e que o realizador capta e faz durar exatamente por se investir de uma função fabuladora.

O que interessa a Coutinho é o instante em que algo irrompe, se acende e se torna grande, especial, sem deixar de ser o que é. O que chamei de dispositivo fabulador se relaciona com o que Lins chamou de "dispositivo relacional", que tem por função "deslocar e dissolver, mesmo que provisoriamente, formas enrijecidas de perceber a si mesmo, o mundo e o outro, abrindo assim novas possibilidades para novas maneiras de ver e ser" (LINS, 2009). Mas esse dispositivo relacional só faz isso, a meu ver, porque se inscreve no interior de uma máquina estética, nas linhas de um dispositivo de invenção que "organiza” esse mecanismo de deslocamento.

No filme, é, portanto, a fabulação, e não a lembrança, que conserva e ao mesmo tempo faz retornar essa sensação como um "motivo" no filme, como um ritornelo, conceito crucial de Deleuze e Guattari, que eles criaram para designar esse "conjunto de matérias de expressão que traçam um território e que se desenvolvem em motivos territoriais, em paisagens territoriais" (DELEUZE; GUATTARI, 1980, p. 397). É graças à fabulação, mas também a essa constituição de "motivos" ou "paisagens" no filme que os personagens e suas lembranças adquirem uma dimensão particular que os "agiganta" e os torna tão reais e potentes. É assim que cada narrativa se investe de uma qualidade intensiva que se expressa na forma-história ou na forma-canção.

Ao mesmo tempo, isso tudo só é possível por causa da constituição de um "território" que é próprio de Coutinho, um conjunto de relações de espaço-tempo que ele delimita, forja e que modela também seu próprio "fazer cinema” e toda matéria de expressão que esse "fazer" mobiliza. Na verdade, como tentei 
demonstrar, são suas maquinações, suas estratégias narrativas e suas personagens que se inscrevem nesse "território de invenção" como ética estabelecida pelo dispositivo fabulador. É nesse "território", onde o próprio Coutinho, uma vez instalado, se repete e cria, produz variações e ritmos, motivos, passagens de coisas de um estado a outro, ritornelos que exprimem essa relação territorial. É por meio dessa ética de invenção que ele próprio fabula e se agiganta quando faz cinema. 


\section{Referências}

BADIOU, A. Ética: um ensaio sobre a consciência do mal. Rio de Janeiro: Relume Dumará, 1995.

BARROS, E. "Eduardo Coutinho fala sobre As canções, seu novo filme”. Jornal do Commercio, Recife, 6 jan. 2012. Disponível em: <http://jconline.nel0.uol.com.br/canal/cultura/cinema/ noticia/2012/01/06/eduardo-coutinho-fala-sobre-as-cancoes-seunovo-filme-27803.php>. Acesso em: 31 jan. 2012.

BENJAMIN, W. Magia e técnica, arte e política: obras escolhidas, v. 1. São Paulo: Brasiliense, 1993.

BERGSON, H. Matéria e memória. São Paulo: Martins Fontes, 1999.

DELEUZE, G.; GUATTARI, F. Mille plateaux. Paris: Les Éditions de Minuit, 1980.

O que é a filosofia? Tradução de Bento Prado Jr. e Alberto Alonzo Muñoz. Rio de Janeiro: Ed.34, 1992.

Imago, 1977.

Kafka: por uma literatura menor. Rio de Janeiro:

GONÇALVES, F. Fabulações eletrônicas: poéticas da comunicação e da tecnologia em Laurie Anderson. Rio de Janeiro: E-papers, 2006.

LATOUR, B. Reensamblar lo social: una introducción a la teoría del actor-red. Buenos Aires: Manantial, 2008.

LINS, C. "O documentário expandido de Maurício Dias e Walter Riedweg". 2009. Disponível em: <http://www2.sescsp.org.br/sesc/ videobrasil/site/dossier028/ensaio.asp>. Acesso em: $1^{\circ}$ nov. 2012.

. "O filme-dispositivo no documentário brasileiro contemporâneo”. In: Sobre fazer documentários. São Paulo: Itaú Cultural, 2007. Disponível em: <http://www.itaucultural.org.br/ bcodemidias/000484.pdf>. Acesso em 6 fev. 2012. 
SIMONDON, G. L'individu et sa genèse physico-biologique. Paris: Presses Universitaires de France, 1964.

TARDE, G. Monadologia e sociologia: e outros ensaios. São Paulo: Cosac Naify, 2007. 


\section{Super-heróis, intrépidos, caretas: cultura jovem na publicidade e no documentário das marcas Shell e Esso nos anos 60 e 70}

/////////////////// : Andréa França

\section{Cláudia Pereira}

1. Doutora em Comunicação pelo Programa de Pós-graduação em Comunicação e Cultura da Universidade Federal do Rio de Janeiro. Professora do Programa de Pós-Graduação do Departamento de Comunicação Social da Pontifícia Universidade Católica do Rio de Janeiro. Pesquisadora do Conselho Nacional de Desenvolvimento Científico e Tecnológico. E-mail: afranca.pucrio@gmail.com

2. Doutora em Antropologia Cultural pelo Programa de Pós-graduação em Sociologia e Antropologia da Universidade Federal do Rio de Janeiro. Professora do Programa de Pós-Graduação do Departamento de Comunicação Social da PUC-Rio. E-mail: claudiapereira@puc-rio.br 